\title{
MACHIAVELLI AS POLITICAL THINKER
}

The name of Machiavelli is probably better known than that of any political thinker with the exception of Aristotle and Plato. Yet this notoriety was won by a little pamphlet which can be read in two hours, to which he himself only attributed a transitory importance, and which, according to Hume, contains nothing which everybody did not know already. Machiavelli wrote much else-a treatise on Livy, a long history of Florence, a novel, plays, diplomatic reports, and private letters. Few besides hardened historians or inquisitive men of letters ever look at these. I should doubt if 5 per cent. even of this enlightened audience ${ }^{1}$ have read through the Discourses upon Livy, upon which the writer expected his fame to rest. The Prince, and The Prince alone, has given him immortality. Since it was first printed, it has been the theme of volume upon volume in every European language; it is the subject of warm controversy to the present day. The literature, in fact, has become so vast that in an hour's space I can only flutter across the characteristics of the book, the origins of its composition, and the secret of its interest.

Machiavelli was born in 1468 and died in 1527 . The year 1512 marks a conveniently sharp line between the two aspects of his career. From 1496 he had been the highly-placed, hardworked Civil Servant, Secretary to the Ten, the Committee for Military and State Affairs. After the fall of the Republican Government inaugurated by Savonarola, and the return of the Medici to Florence, he was excluded from political life, and relegated to his little, very countrified estate at San Casciano. Here he had only too much leisure for his active tastes, and here he read and thought and wrote. Fortunately, from time to time he enjoyed the stimulus of the most cultivated set in Florence, which met in the beautiful Rucellai Gardens, and discussed the drafts from which his works were later published. Late in life he was reconciled to the Medici and commissioned to write his history of Florence, leading up to the glorification of that House.

Sharp as the contrast is, the first period had an immediate influence upon the second. The official had accumulated the

2 This paper was read at University College, London, on March 4, 1920.

No. 18.- - voL. v. 
evidence upon which the philosopher's conclusions were based. His experience for a public servant of no great family had been extraordinarily wide. He had been sent, not indeed as ambassador, but as observation officer to France, to Germany-that is, to Switzerland and the Tyrol-to Cæsar Borgia, to Julius II. He took a principal part in negotiating the surrender of rebellious Pisa after the wearisome war of fifteen years. Above all, he had shown some practical ability in initiating and organising a native Florentine militia which was to replace unreliable auxiliaries and corrupt condottieri. The militia, by running away from Spanish regulars at the storming of Prato, had really caused their founder's fall, but the civilian was justly proud of his military achievement, which was indeed the key to bis future writings.

With most men study precedes experience; by Machiavelli experience was applied to study. After his disgrace he could devote his time to the ancient historians, whose works had always excited his interest, e.g. during one of his missions he wrote with urgency for a copy of Plutarch's Lives. Many of you have read the letter which tells how, after a sordid and squalid day, he puts off his dirty, muddy clothes, dons royal robes and enters the courts of the great ancients, holds converse with them, and feeds on the food which alone is for him, and for which he was born. In those four hours be forgets his worries, he fears not poverty, has no dread of death, is all absorbed in those classic authors. Machiavelli was too industrious to be content with reading, which is the easiest form of indolence, or even with thinking, which by itself is barren; he must needs be doing, and the only activity possible was to write. He settled down to a commentary on the First Ten Books of Livy, because be saw in the Roman Republic the ideal State, well-balanced as between the classes, possessing in the consulate an element of efficient monarchy, and above all so fully armed that it was able to compass the unity and peace of Italy. Italians were after all Romans; could they not revert to their original principles, could not a model republic be revived on the old Roman model? To this commentary he gave the title of Discourses on the Decades of Titus Livy.

What was Machiavelli's aim in writing the Discourses? Much the same as that of Aristotle in writing the Politics, though he took a different way of reaching it. Both strove to discover the ideal form of government; with both, the practical test was stability, for in Italy, as in Greece, the lack of stability had been the fatal flaw. Aristotle's method was the analysis of all existing forms, nor did he despise that of ideal systems such as Plato's. 
Machiavelli was too pessimistic for the former process, and too practical or sceptical for the latter. Contemporary Italy was too corrupt to offer any gleam of light, with the exception of Venice, but her constitutional excellence was in his opinion outweighed by her vicious military system. He did, indeed, turn to France as presenting in her Parliament a model of justice, and once to England to praise her exercise of arms in time of peace. He had, however, this advantage over Aristotle, that there was a long historical past behind him. There is a universal tendency to look back upon the past as a golden age, or at least a superior age. Thus then Machiavelli, as Dante, being Italian, looked back to an age when Italy was really great, with this difference, that Dante idealised the Empire, and Machiavelli the Republic. Machiavelli was a republican by instinct and profession, and was not wholly disillusioned by the calamity of the Florentine Republic. His remedy was in politics, as in religion, in law and medicine, to revert to first principles. St. Dominic and St. Francis had for a time stayed the corruption of Christianity by restoring the ordinances of its founder. Machiavelli would do the same for the State by minute research into the history of the greatest republic that had as jet existed, that of Rome. Petrarch, he would have said, had made a fundamental error in drawing a hard-and-fast line between ancient and modern history. Roman bistory was not merely a collection of interesting incidents, useful only for rhetorical ornament; it was for those who read it with insight (sensamente) an infallible lesson for the present. In the State as founded by Romulus and continued by Numa he found good arms and good religion. These were the irreducible minima. Without good arms you could never have good laws, without religion good arms would only end in anarchy. On the foundations laid by the Monarchy the Republic built up the Roman State.

If Machiavelli was so deeply interested in the Roman Republic and its possible adaptability to existing Italian needs, why did he suddenly turn from it to compose The Prince, the very negation of a republican system and having no relation to præ-Imperial Rome? The immediate reason, perhaps, was that he was out of work and poor; his active mind longed for exercise, and his material instinct for the flesh-pots of Florence. The natural, the inevitable recourse was to a patron. There seemed no more chance for the Republican government that had been overthrown; Machiavelli's late chief, Piero Soderini, had been led weeping from the Palazzo by four young aristocrats, and was now an exile at Ragusa. The Medici were firmly in the saddle at Florence, with the good- 
natured Giuliano as their representative, while his brother Leo X. supported him with all the power of the Papacy. If Machiavelli had personal feelings of hostility, it was rather to the aristocrats who had betrayed the Republic than to the Medici who took advantage of the treason. After all, Machiavelli had not been one of the rulers of the State, but a mere employé. Why should he not be as useful to a new prince as the Kaiser's minister, Dr. Solf, to a new Republic? Guicciardini later adopted the same course, and his defence applies to Machiavelli.

This is the material, external side of the question, which makes The Prince a livre de circonstance, a personal bid for office. But there is more than this. Machiavelli had a gospel to preach, that of Italian liberty. He had seen with his own eyes his country disgraced and destroyed by French, Germans, Swiss and Spaniards. If Venice with all her power had been overthrown, what chance could there be for Florence, which without ruinous foreign aid could never even have recovered her own rebellious city of Pisa? Italy had sunk so low that to be freed she must be re-created. For creation Machiavelli always held that individual energy was essential; a State must be started on its course by a personality, a Romulus, a Moses, a Theseus, a Cyrus. He could not even conceive of the French institutions, which he admired as a model of constitutionalism, as being a growth; for him they were the conscious work of some unknown founder in the past. Here, then, comes in the individualism which is so prominent a feature in the Italian Renaissance. But also, as a clever and experienced bureaucrat, he had acquired the cult of efficiency. He must regretfully admit that democracy, as far as he knew it, was abandoned to the cult of inefficiency. In Italian city states Republican constitutions had almost all given place to despotisms, because this was the sole refuge from the anarchy of faction. The Golden Ambrosian Republic of Milan, which had started with such bright hopes, had split into fragments the great Visconti State, the nearest approach to unity that Italy had known, and had ended in an orgy of mob rule and fallen a prey to an efficient soldier. The Savonarolist Republic of Machiavelli's own day had shared the fate of that of Milan, and yet she had in Savonarola her individual creator, her prophet, her Moses; but then he was inefficient, because he was unarmed. Even Venice, admittedly the best model of the mixed state for which Machiavelli had been searching in the Discourses, had failed in the supreme test of war.

At such a crisis could his patriotism be content with the arid and stale discussion of Aristotle's analysis of constitutions handed 
down from generation to generation and reaching him, not through the original, but through Polybius? Might he not exclaim with Pope : "For forms of government let fools contest, whate'er is best administered is best"? The times needed a creator who must be efficient, and, to be efficient, must be armed. With such an one he had been brought into close contact; during his mission to Cæsar Borgia he had won his favour, received his confidence; this was the most exciting episode of his life. Cæsar had actually created a new considerable state, which might, thought Machiavelli, have been a nucleus for a united Italy; he had got rid of his mercenary captains, and rendered himself less dependent on his French auxiliaries by the introduction of national service, from which Machiavelli had copied his own scheme. Cæsar had, indeed, failed, but this, thought Machiavelli, was due to an accident, his own illness at the moment of his father's death. He must then find a replica of Cæsar, of whom he writes, "I should not know what better precepts to give to a new prince than the example of his actions." "I shall never hesitate to quote Cæsar Borgia and his actions." For his replica of Cæsar, Machiavelli naturally turned to the ruler of his own state. Italy could not be united by a Florentine Republic ; it might be by a despot working from Florence as his base. The popular house of Medici, backed by the power of the Papacy, stood surely a better chance than the hated alien house of the Borgian Pope and his bastard. When Giuliano died, Machiavelli transferred the dedication to his nephew Lorenzo, who had more youth, more violence, more ambition. Lorenzo took no notice of the disgraced civil servant's brochure, and Machiavelli's sole reward for his trouble was a reputation enviable or unenviable with posterity.

By my title I have begged the question whether Machiavelli is a political thinker, but I suppose that any man who really thinks much upon politics, and does not merely think that he thinks, may claim the designation. Can we place him a stage higher and call him a Political Philosopher? This implies originality, constructive power and method. Where then is his originality? Why has he been called the founder of a new epoch in political science, the first philosopher since Aristotle and Plato? Why, again, has he been singled out as being præ-Baconian? Bacon himself has supplied a partial answer in what may be called a grace to be repeated before sitting down to a feast of Machiavelli's works: Gratias agamus Machiavello et hujus modi scriptoribus qui aperte et indissimulanter proferunt non quid homines facere debeant sed quid faciant. In Bacon's opinion be discredited the utopia; he certainly 
caused a reaction against the formal panegyric, the formal diatribe, the literary stock-in-trade of the Renaissance, which devoted its talents to form rather than to thought. His conclusions were founded on facts, on personal observation and historical analysis. His method has been called inductive-historical is a better phrase, because in so huge a field as that of politics induction must be so incomplete as to be almost worthless. In his own words, "I have thought fit to follow the actual truth in my subject rather than an imaginary view of it. Many have imagined republics and principalities which have never been seen or known to exist in reality, for there is so much difference between how one lives and how one ought to live, that he who leaves what is actually done for what ought to be done is learning the means to his ruin rather than to his salvation, for a man, who under all circumstances wishes to make what is good his object, must necessarily come to ruin among so many who are not good." Politics, that is, must be studied by and for themselves, they must not be confused by ethics or religion. Historical his method certainly is. From the lessons of Roman history he laboriously feels his way towards the formation of a model republic, for The Prince he selects his instances partly from the Roman empire and the Macedonian monarchy and the tyrants of Sicily, partly from his own experience of Cæsar Borgia. The third work of the trilogy, the Arte della Guerra, is, as has been admirably shown by Mr. Burd, almost a cento of quotations from classical authors artistically woven into a treatise half military, half political.

At times, however, the uncomfortable question arises: Is his history always apposite, and, if not, what is the value of the lesson to be learnt from it? Guicciardini's critical faculty at once fastened upon a flaw. "How greatly do those deceive themselves, who at every word quote the Romans. It would be necessary to have a state under the same conditions as was theirs, and then to govern on that model; but when the respective characters are out of all proportion, the attempt also is as much out of all proportion as it would be to set an ass to run a horse race." Machiavelli in other words does not always argue in pari materia. If only he had left Rome alone and put side by side with Cæaar Borgia, as he very occasionally does, the despots of Milan, Verona, Padua or Rimini, The Prince would have been a precious handbook of Italian medieval history, worthy of being set side by side with Aristotle's Politics, the very grammar of Greek history. Guicciardini's criticism might be carried further still ; it might be argued that Machiavelli's conclusions rest not always on 
proofs but on authority, that a text of a Latin author counts as much to him as a text of scripture to Dante and his contemporaries.

Hence the extraordinary contrast between the sagacity bred of experience in the Florentine Chancery, and ripened by diplomatic opportunities at home and abroad, and the plagiarist commonplace derived from solitary study of moralising historians. The pedant and the politician were never so curiously blended as in Machiavelli.

And yet, further still, is there not in Machiavelli's political works an element of the utopia, an imaginary ideal state, ideal not indeed for the governed but for the government? "It is an unsafe thing," says Harrington, writing on Machiavelli, "to follow fancy in the fabric of a commonwealth."

I need not dwell on other faults of Machiavelli, on his frequent contradictions, on his using the self-same fact to prove two opposite conclusions, on his somewhat shameless selection of his. evidence, of which I will give a single instance. In pushing his military hobby to its extreme, he says that every successful ruler must be a soldier, leaving out of sight Gian Galeazzo Visconti, who was far nearer giving unity to Italy than Cæsar Borgia or Francesco Sforza, or Charles V., the most successful king of France, who spent his time on his knees rather than in the saddle. These latter faults are natural, for Machiavelli was writing with a view, not to abstract philosophical truth but to practical politics, and what political writer does not pick his instances and doctor his statistics? But also this predisposition to formulate, according to his favourite phrase, "a rule which never or rarely fails" is a defect of his quality, of the piercing vision which looks through and behind the facts to principles. He clutches at principles, and is too impatient to collect its proofs.

Machiavelli was always searching for method but never quite found it. His want of scholarship made him uncritical as to his sources and to the conclusions to be drawn from them. Method, after all, is the instrument of constructive power, and of this he had but little. The form of the Discourses, it is true, being a collection of notes on chapter by chapter of Livy, did not lend itself to construction, though he might derive therefrom some general principles of interest. The Prince is more compact, it has some sort of plan, but the scheme has little originality and no completeness, it is little more than a series of maxims for government by force or fraud derived from the existing or historical despotic state. As a work of philosophy, it cannot be compared with the 
Defensor Pacis of Marsiglio, or even with the De Monarchia of Dante. It is not even an utopia, because this is a constructive work of the imagination, even as a political philosophy is that of the intellect. An utopia, such as that of More, or of Campanella or Butler's Erewhon, professes to picture the whole framework of a dreamland people. No one can claim this for The Prince, though it has been called an utopia not for the governed, but for the government. There is, however, in an utopia an element of prophecy, looking forward to a future better than the present or the past. Machiavelli was no prophet, unless a prayer for Italy's unity, when it was quite impossible, constitutes a prophecy. In this there was no originality, for poets had sung of it; rulers before his day, such as Gian Galeazzo, had thought it almost within their reach; and many, among them Machiavelli himself, feared in his own time that such was the deliberate aim of Venice.

Machiavelli's insight, acute as it might be, was confined to facts, to specific objects. He was too short-sighted for distances, he had no sense for atmosphere. Even while he wrote, there were great, if distant, events in the far East and West which would reduce to yet lower insignificance the petty States of Italy, which were all his world; there were movements of thought, which long before his death would shake all Europe, but all these were outside his focus and foreign to his feeling. The Prince gives no real evidence of constructive power whether philosophical or imaginative. The realisation of his scheme would have been a mere mechanical extension of a faulty system from one territory to another until his buckram hero misgoverned the whole of Italy.

How is the more fundamental weakness in Machiavelli's philosophical structure to be explained? I think by his belief in the theory, common in his day, of an historical cycle; there is always a definite amount of evil and of good in the world, neither more nor less; a given nation never stands still, it is always ascending or descending, but cannot escape from the cycle, cannot in fact progress. Thus, it is often said that Machiavelli had no idea of progress, of evolution, which is the cardinal feature of most modern political science. Thus revival takes the place of reform, whether political or religious. As St. Dominic and St. Francis reverted to the practice of the early Benedictines, and the spiritual Franciscans to that of St. Francis, so the Italian politician must hark back to the system of his forefathers, the ancient Romans. Yet, even so, he is not quite logical, for he seems to think it im- 
possible that this latter goal should ever be really reached. Italy, the corruption of the world, was obviously at the bottom of the wheel, and Machiavelli despairs of her ever reaching the top. This is what is called Machiavelli's pessimism, which is at once historical and ethical. He was a disappointed man, had seen little of the better side of human nature, his own moral standard was distinctly low. For him, men were by nature bad and not good; if ever they were good, it was because they were forced to be so; "of men, speaking generally, it may be said that they are ungrateful, fickle, deceitful, cowardly, greedy; as long as they are getting anything out of you, they offer you their blood, their goods, their lives, their children, when the need seems far distant, but when it is near at hand they turn against you." The people being bad, the ruler cannot be good, for to be good would be his ruin, the ruler must be what his subjects make him, he must have no good faith, no mercy, no scruples, no half-measures; he must be beast as well as man, fox as well as lion, must pretend to be what he is not, and pretend not to be what he is. He may have personal virtues or vices, but he must select from each category those which will not prejudice his power. The people, bad as they are, for selfish reasons, would like their prince to have all the virtues. So he must appear peaceful, faithful, humane, honest, and, above all, religious. The most successful ruler of his time was Ferdinand of Aragon, who used religion to justify all. his enterprises, however cruel. The cant of Ferdinand, the force of Borgia, are the essential qualities for all rulers to acquire. It must be noted that this doctrine is preached by Machiavelli, not only in The Prince, which is a somewhat fancy sketch of a typical Italian despot, but in the Discourses, where the people are to have their full share in the government. Truly a melancholy picture, no wonder that it would be found in practice that no policy that could be adopted could be good; all that could be done was to choose the least bad-the last word in political pessimism.

If Machiavelli's philosophical method was defective, if the subject of the Discourses was an ideal Italian republic, which never was and never could in those days have been founded, and that of The Prince a despotism which has revolted future generations, and that of the Art of War a civilian's military text-book which decried the use of gunpowder, why do we persist in paying so much attention to his works? Partly, no doubt, for the perfection of his style. Partly, also, for his patriotic cry for a free and united Italy, to which we shall return. But apart from style and patriotism, from a purely politico-philosophic point of view, the study of the Dis. 
courses and The Prince is well worth while, for they touch on the relation of the individual to the State, which still perplexes us, and must always do so. Here it is that the study of antiquity by so penetrating and so modern a thinker has proved a real contribution to political thought. Machiavelli learnt from both Greece and Rome that the State must be supreme, but he had more affinity with Rome than Greece. For the individualist development of the Italian Renaissance the Greek state was perhaps too all-absorbing, it dominates too many sides of the individual's activities. Many of our own problems Machiavelli scarcely touches. He never treats of education (though he may presuppose a training in the $\dot{\eta} \theta 0 s$ of the State). On economics, which fill the largest place in a modern work, he merely advises the prince not to tax too heavily, and not to confiscate his subjects' land; he quotes with approval the voluntary taxation on Auberon Herbert's lines, which he found in Switzerland. On the relation of the sexes, he has no word beyond the suggestion that the best way to win a woman's affection is to beat her. Yet, his successor, Campanella, reverts, in his City of the Sun, to the extremist views of Platonic sexual-communism and to equality in the service and the privileges of the State. In only a few sentences does he refer to the ruler's duty to protect and further agriculture and commerce by appropriate bonuses, and to encourage by his presence popular gatherings for feasts and spectacles, and yet these were prominent features in the policy of most Italian states whether monarchical or republican.

Machiavelli had more affinity with Rome than with Greece; he prefers the intensive but more limited range of the Roman state, which may be summed up in one word-Discipline. That was what Italy and, above all, Florence needed. Livy taught Machiavelli that the power of Rome rested on religion and on arms, i.e. on spiritual and physical discipline. In the 14th century, the religious question had taken the form of the relation of the civil power to the Papacy. This had been almost the whole purport of Dante's treatise, and the most interesting topic in that of Marsiglio ; the contest raged for centuries through every state in Europe. Machiavelli's peculiarity is that he adopts almost in its entirety the præ-Christian governmental point of view, though, except in one respect, he has no quarrel with Christianity. The passage in question suggests that Christianity weakened the war-like, virile character of the citizen by unduly exalting meekness and humility. To the text "the meek shall inherit the earth" he would reply, "the meek might 
inherit, but the war-like might say: "This is the heir, come let us kill him." "Even this criticism he watered down by adding that it was probably not a correct representation of the Founder's teaching. Machiavelli had, indeed, no use for an unarmed prophet such as Savonarola, who, in spite of saintliness and his early popularity, fell because he was at the mercy of a riot. As against this, the simple people of Switzerland and the Tyrol were at once the most Christian and the most war-like. Machiavelli's quarrel with the Papacy was not that it was Christian, but anti-Christian, antireligious, that thanks to it the three Latin nations had become the corruptest of the world, that religion flourished in inverse proportion to its nearness to the Papacy, that, if this were transplanted across the Alps, the German nations would soon become as corrupt as the Latin. For Machiavelli as for Dante, the chief cause of this corruption was the temporal power of the Papacy, and this he felt the more strongly because it thwarted his ideal of a united Italy. Machiavelli had, indeed, like Dante, been singularly unlucky in his Popes, Sixtus IV., Alexander VI., Innocent VIII., Julius II., a far from reputable partie carrée (the few months of Pius III. may be omitted).

Machiavelli has often been misrepresented as holding that religion was merely an instrument of government. An instrument it might be, but it was much more. It was part of human nature, and no ruler could neglect it-nay more, it was the very base of a well-ordered state; there was no better proof of the decadence of a nation than the contempt for divine worship. The Roman republic owed her two centuries of glory even more to Numa than to Romulus, for religion is essential to the maintenance of una civilta. The Samnites in adversity found in the revival of religion the only hope of regaining their lost manhood. Thus, he warns the new prince to respect and even encourage the ceremonies and superstitions of his subjects even if he does not believe in them. If the prince has no religion, he must, at least, pretend to have it; Ferdinand of Aragon owed most of his success to making religion the cloak of his most striking enterprises. The unity and character of a state depended on religion. If religion had been maintained in the Christian states, they would be far more happy and united than they were. Where there is religion, arms can be introduced; where there arms and no religion, the latter can with difficulty be revived. Machiavelli was probably an agnostic, but he cannot be fairly called an atheist, and he deserves credit for a wide tolerance. William the Silent has often been credited with the invention of religious tolerance; he had only to read Chapters 
11 and 12 of the Discourses to find it. Were Machiavelli alive now to discuss the place of religion in education, he would with certainty be undenominationalist, but not secularist.

However much Machiavelli respected religion, his personal interest was in arms. Good order required good laws, and good laws could only be enforced by good arms. Thus, the Roman military system became the foundation of all his political thought. Both the Discourses and The Prince work up to this and it receives its completion in the Art of War. He had seen the Roman system practically adopted by the Swiss, so thoroughly, indeed, that at one moment he had a panic fear that they would conquer all Italy. But to have good arms the State must be supreme; the individual must sacrifice his liberty, and, if necessary, his life to the State. The system advised was so rigorous that no modern nation adopted it until Prussia set the fashion. Yet, Machiavelli was not militarist in the Prussian sense. Soldiers and officers were to remain citizens; a campaign ended, both returned to their normal civilian occupations; a military caste he would have regarded as an evil as great as the condottiere system. But the chief duty of the ruler must be the training and upkeep of the national army. For this purpose, a prince doubtless had advantages over a republic; the wholly imaginary Castracane and the not wholly real Cæsar Borgia were made his models. But this did not entail irresponsible autocracy, for the whole people could not be armed, unless the whole people consented. And a popular army must consist mainly of infantry, and thus infantry comes to be the backbone of a national force.

This popular service leads to another side of Machiavelli's principles, which has a very modern bearing, that is the share of all classes in the service and in the government of the State. His instincts are radical, he believes in the people rather than in the upper classes; from the governmental standpoint, rule based upon the people is more durable; the people is more loyal, more easily satisfied; it wants, not to oppress, but merely not to be oppressed; ignorant as it may be of general principles, it has a sound instinct for particulars. Against the upper class Machiavelli seems to have a personal prejudice, yet he would not exclude it from the construction of the State. Even the despot of Cæsar Borgia's type cannot dispense with either people or nobles; he must rely upon the people, but must also satisfy those humours which, being unsatisfied, lead to trouble. It must be remembered that the people, in Machiavelli's sense, would include the middle class, a large and intelligent body in Florence. Government, then, 
must not rest on Junkerism, on bourgeoisie, or on labour; it must be compacted of all classes. All must be enlisted in the service of the State; the State must be framed for the benefit of all classes, but it must control all classes. If such a State were to expand, and Machiavelli meant it to expand to the limits of all Italy, the provinces annexed must be made, not subjects, as was the usual Florentine practice, but companions, as in ancient Rome; the Italian State would be in a sense a federation of provinces, resembling that of the Swiss cantons. Here at last in the Discourses rather than in The Prince there is evidence of constructive thought. Outside the limits imposed by the State free play was left for individual tastes and energies, but within them the State was all in all and over all-Deutschland über alles in the true sense of that much-abused phrase.

These subjects of modem interest are illustrated in the Discourses rather than in The Prince, and yet it is on the latter alone that Machiavelli's fame has rested. How is the extraordinary vogue of this little pamphlet to be explained? In great measure by the date, not of its composition, but of its publication (1531). The second expulsion of the Medici, the revival of fierce republicanism with the martyred Savonarola as its prophet and the Holy Ghost as its patron, the gallant defence of Florence and its tragic fall produced a violent reaction against Machiavelli as being in The Prince the parasite, in the History of Florence the panegyrist of the Medici. European interest was aroused. The Prince became the text-book for would-be absolutists, the target. for lovers of liberty. The question was one not only of politics, but of ethics. No one had ever stated the cause of the Is against the Ought To Be so trenchantly as Machiavelli. This had been to his contemporaries an academic commonplace, but to the stirred consciences of the Reformation and the Catholic Revival it was a vital question of morals. Jesuits and official Papalists denounced it as subversive of religion and Papal authority, Protestants as dangerous to morals and to liberty. The indifferents, the realists, the new men of science, rallied to Machiavelli's defence. Do the same principles apply to State and to individual practice? Is there a national as there is a personal conscience? The controversy was afoot, and every newspaper editor knows how much easier it is to start a controversy than to stop it.

The interest in Machiavelli's call for the liberation of Italy was more intermittent, but it naturally rose to fever-heat with the Risorgimento in the middle of the last century. Dante, who had summoned a German Emperor to give peace to Italy, fell 
out of favour, and Machiavelli, who had called upon Italians to expel the foreigner by force of arms, became the popular literary hero. And yet of the two greatest figures of the Risorgimento Mazzini condemned him as causing the moral ruin of Italy, and Cavour preferred Guicciardini as the better guide for the practical statesman.

This call, however, contained in the last chapter of The Prince, and somewhat loosely attached to the structure of the pamphlet, is in chief measure the true cause of the writer's fame, and that for the beauty of its words. It is probably the finest patriotic cry that ever issued from any language. It gave value to the little book, which was aided by its very shortness and its very easiness. And here we have reached Machiavelli's chief claim to immortality. He had an incomparable style, the least ornate, the least redundant, the most simple and direct, the clearest and most forcible of all Italians of his day, or perhaps of any day. It is at least remarkable that his two works which are at all widely read, The Prince and the History of Florence, are those which best lend themselves to the display of style. Of these The Prince is the finer as being the younger, the less laboured and conscious. His style is so perfect because it is so genuine, because it comes hot from the furnace of his feelings or his thoughts. Had he been a characteristic Renaissance Humanist, he would have cast about for added ornament; the product would have cooled and lost its savour. Most of us find that we cannot write as vividly as we think; there is a gap between the thought and its expression. With Machiavelli it was not so. Whatever his contradictions, he felt so keenly on the subject which he was treating that thought and expression were almost simultaneous.

A recent writer, Alfredo Oriani, has called him the painter of politics, his gift being that of the brush rather than of the brain. His art is pictorial rather than philosophical; The Prince is a flash-light representation of the policy of an Italian State as Machiavelli saw it. Others have called him the reviver or creator of political thought. Oriani, who sets no value on his philosophy, proclaims him, more truthfully to my mind, the creator of modern Italian prose, and that is glory enough for any man.

E. ARMSTRONG 